\title{
Locating Gendered Representation in European Union Member States
}

\author{
Andrea S Aldrich, Yale University \\ Andrea.aldrich@yale.edu \\ ORCID: 0000-0003-4418-254X \\ William T Daniel, University of Nottingham1 \\ William.Daniel@nottingham.ac.uk \\ ORCID: 0000-0003-2160-4033
}

\begin{abstract}
While the EU does not set specific legal requirements for its member states' electoral systems, it is perhaps one of the world's best learning laboratories for comparing the effects of electoral design. The EU is also, in many ways, a leader in the policy space of gendered representation - with a proportionality principle roughly applied across the Commission and Court of Justice, as well as one of the most descriptively representative spaces for female legislators in the European Parliament. In this chapter, we assess the role of the EU in the promotion of women's descriptive representation. Using the broad variation found in national electoral laws and party organization guiding policies, we are able to assess how national expectations of gendered representation commingle within the EU legal space. In doing so, our work brings to light new descriptive information on the state of gendered representation at the EU, national, and party levels of Europe.
\end{abstract}

Keywords: gender, representation, European Union, legislative elections, political parties

\author{
Forthcoming in Research Handbook on the Politics of EU Law \\ (Paul James Cardwell and Marie-Pierre Granger, Eds.), Edward Elgar.
}

\footnotetext{
${ }^{1}$ Authors' names appear alphabetically to denote equal work. The corresponding author is William Daniel, William.Daniel@nottingham.ac.uk.
} 


\section{Locating Gendered Representation in European Union Member States}

\section{Introduction}

Whereas the concept of proportionality in the European Union is typically the most-closely associated with the so-called 'proportionality principle' set within the Union's constitutional order (cf. Article 5, TEU), a high degree of proportionality - or perhaps proportionalities - also exists in the design and functioning of the European political institutions. From the 'degressive proportionality' of the European Parliament's (EP) seat allotment and its proportional representation elections - mandated by EU law, to the consensus-based Qualified Majority Voting (QMV) of the Council and historical "Luxembourg Compromise" for major decisiontaking, a spirit of consensus and proportionality has long permeated throughout the EU. Perhaps for this reason, the EU is also oftentimes noted as a leader in gendered representation, both in terms of the number of women in powerful positions across EU institutions, but also in terms of the policies advanced by them.

As with the other areas discussed in this volume, the interaction between law and politics is at least partly responsible for the EU's successes in promoting more equal representation between men and women than is observed in many of its member states' national governments and indeed across most of the world's liberal democracies.2 In this chapter, we first set out to define and discuss the multi-faceted concept of gendered representation, before detailing how both 'hard' legal and 'soft' social choices have been taken by the various EU institutions to promote more equal representation for both women and men. We then conclude with a discussion of various areas for future research in the domain of gendered representation within the European integration process.

While our perspective assumes a heavily social scientific and institutionalist bent throughout, we are quick to highlight ways in which our view of laws, regulations and norms at the EU, national and political party levels should also be of interest to the broader legal scholarship community.

\section{Defining Gendered Representation}

Social scientists oftentimes link empirical discussions of gender parity in political life with issues of political representation. While the concept of representation in politics is itself complex and multi-faceted,3 gendered representation is typically framed in either 'descriptive' or 'substantive terms.' Descriptive representation - sometimes also referred to as 'numerical' representation - denotes political systems in which representatives 'look like' the populations that they represent. In terms of gender, this typically brings to mind political systems with relatively high degrees of gender parity - as would also be expected in the broader population.

Whereas descriptive representation can oftentimes promote increased women's participation in political life, 4 it may also lead to broader political discussions about policies that also impact

\footnotetext{
${ }^{2}$ See also Tryfonidou in this volume on LGBT rights, who notes the early commitment in the Treaty to gender equality.

3 See, for example: Pitkin, Hanna. 1972. The Concept of Representation.

https://www.ucpress.edu/book/9780520021563/the-concept-of-representation (June 5, 2019).

${ }^{4}$ Wolbrecht, Christina, and David E. Campbell. 2007. "Leading by Example: Female Members of Parliament as Political Role Models." American Journal of Political Science 51(4): 921-39.
} 
on women's issues. This leads us to the second concept - substantive representation - whereby governments are not just being led by equal numbers of women, but are also passing policies that specifically have positive benefits for female populations.

Of course, if beneficial women's policies oftentimes require the presence of female decisionmakers, then the question becomes how to ensure a large enough degree of women's representation. Matland provides a useful framework for this story.5 Ideal recruitment environments for female politicians are predicated first on a combination of economic development, a broad culture of gender-based equality, and electoral systems that are permissive in favoring women's election. These must then be paired up with political partybased recruitment structures that combine formal rules and informal norms to boost the recruitment of women to electoral contests.

In other words, Matland argues that to boost women's policy issues, there must first be elected women. And to boost elected women's numbers, there must be parties that actively recruit them for office and provide them with the resources to actually win election. And, finally, this system must be embedded in a positive environment that supports women's recruitment in the first place. 6 As put more bluntly by Fox and Lawless, 7 women oftentimes do not bother to run for office, simply because no one has asked them to do so. The question then becomes - how do European countries - either through or alongside the EU - work to create such an environment?

If the work discussed above paints a broad picture of a desirable environment for women's promotion into politics, political scientists have also picked apart a number of the more prosaic factors that can enhance women's descriptive representation. Within the context of this volume, a number of these variables are particularly present in the national political systems of Europe - as well as at the EU level. Tremblay's volumes outlines four, central needs to enhance women's descriptive representation: (1) permissive electoral systems and political party selectorates; (2) the use of election quotas, in tandem with placement mandates; (3) the presence of certain cultural values within the broader system;9 and, to a lesser extent, (4) a generally high level of socioeconomic status.

While the latter two points relate mostly to arguments of "softer" sociocultural differences and norms that are less straightforward to trace from a legalistic standpoint, the former two are oftentimes "hard" and fast national laws or codified political party policies. We flesh out each point below, incorporating additional research that speaks to how these institutional decisions can lead to an overall presence of women in European political office that extends beyond what is seen in other regions of the world.

\section{Locating Gendered Representation within the EU}

\footnotetext{
${ }^{5}$ Matland, Richard. 2006. "Electoral Quotas: Frequency and Effectiveness." In Women, Quotas and Politics, ed. Drude Dahlerup. New York: Routledge, 275-92.

6 Ibid. p. 279.

7 Fox, Richard L., and Jennifer L. Lawless. 2004. "Entering the Arena? Gender and the Decision to Run for Office." American Journal of Political Science 48(2): 264-80.

8 Tremblay, Manon. 2012. Women and Legislative Representation: Electoral Systems, Political Parties, and Sex Quotas. Palgrave Macmillan.

${ }^{9}$ See also Valdini, Melody Ellis. 2012. "A Deterrent to Diversity: The Conditional Effect of Electoral Rules on the Nomination of Women Candidates." Electoral Studies 31(4): 740-49.
} 
Political representation within the European Union can take place at multiple levels: the European institutions, the national governments, and sub-national or regional positions must each wrestle with the concept of gendered representation. Each of these levels is also exposed to both EU legal expectations and national or subnational regulations - many of which contain a distinctly European 'impulse' (to use the language of Brouard, Costa and König).10 For the purposes of this section, we distinguish between legal-institutional expectations and more general recruitment environments that increase women's representation in each of the three, formal branches of governance.

\subsection{Legislative representation in the European Parliament and the national parliaments}

Among the branches of government, the legislative is an obvious starting point for any discussion of representation. Sub-national, national, and European legislators are oftentimes impacted by institutional choices that come in the form of both systemwide laws (such as national quotas) or narrower organizational choices (such as party-level electoral list strategies). We begin with a discussion of the former, paying specific attention to how different EU Member States' legal choices produce different outcomes in terms of women's representation.

While social science scholars oftentimes make competing claims about the extent to which electoral design can produce reliable representative outcomes, 11 the correlation between certain institutional choices and the presence of women's descriptive representation in legislatures is well-worn within the scholarly literature on politics and gender. Many such studies are based upon Europe's national legislatures and the European Parliament, specifically, given their high rates of female elected officials, as compared with other regions of the world. Among those choices taken at the national level deemed most important for boosting descriptive representation are quotas, rules pertaining to electoral list ordering, and legislative term limits. We discuss each below, before illustrating how their presence can be a boon to women's representation.

Gender quotas, whereby political parties are required to nominate a certain percentage of female candidates in given electoral competition, have been used since the 1970s as voluntary measures within political parties, starting in Sweden and then slowly moving to the rest of Western Europe. However, they have only been required at the national level by a select handful of European countries since the late 1990s. Moreover, while gender quotas have been useful in boosting the number of female candidates, they have not always been as likely to increase the number of female representatives - with political parties oftentimes circumventing the spirit of the law to place women in undesirable positions that are unlikely to be elected.

\footnotetext{
${ }^{10}$ Brouard, Sylvain, Olivier Costa, and Thomas König. 2012. "Delors' Myth: The Scope and Impact of the Europeanization of Law Production." In The Europeanization of Domestic Legislatures, Studies in Public Choice, eds. Sylvain Brouard, Olivier Costa, and Thomas König. Springer New York, 1-19. http://link.springer.com/chapter/10.1007/978-1-4614-1502-2_1 (December 3, 2013).

${ }^{11}$ See, for instance Farrell, David M. and Roger Scully. 2007. Electoral Institutions and the Failure of Parliamentary Representation. Oxford University Press, New York.
} 
This so-called 'glass cliff' effect 12 implies that parties are disproportionately likely to place women either at the bottom of electoral lists - in the case of proportional representation - or in districts where their parties will simply not be competitive to win - in the case of singlemember electoral districts. By way of a particularly egregious example, Polish candidates for election to the Polish Sejm from the national-conservative Law and Justice Party (PiS) were both placed at the bottom of 2011 electoral lists - far outside of electable positions - and then displayed in suggestive campaign photoshoots that referenced the de facto party leader, using the slogan "Kaczyński's Angels".13

Accordingly, the consensus from social scientists is that gender quotas must not only specify a minimum threshold of nominees, but must also include a placement mandate rule, to ensure that women and men are both listed in effective positions. The mechanics of such regulations can take on a number of different forms, from the traditional 'zipper lists' that force alternation between male and female candidates - the whole way down the line - to looser requirements that force parties not to give top spots only to male candidates. For example, Spain requires at least $40 \%$ women on each party's EP electoral lists, but moreover requires that for every group of five candidates on the list, between $40-60 \%$ of this subset must also be women. Similarly, Belgium requires that at least $50 \%$ of EP list candidates be female, but also requires that the first two candidates on each list be of differing genders.14

The results of such laws to boost descriptive representation are quite clear. In comparative work from the 2009 European Parliament elections, Lühiste demonstrates that parties using both quotas and placement mandates in tandem were substantially more likely to increase female descriptive representation. 15 Of course, it is important to note that EP election rules are almost always derived from national election regulations, suggesting these patterns can be most efficiently created from a national legal basis. However, her work also shows that placement mandates can resolve another, more general paradox faced by would-be female legislative candidates: parties seek candidates with incumbency advantages, elected experience, and demonstrable party loyalty. By purposefully enlarging the pool of successful female candidates, parties are also able to invest in a new mechanism to broaden their set of quality candidates for the future. 16

Naturally, a related hurdle for promoting women's election is in the relatively high incumbency rates enjoyed by most (male) legislators. For this reason, Schwindt-Bayer identifies term limits as a key component to the promotion of women's descriptive representation. 17 By forcing the cycling of (male) legislators, seats become available that will be more likely to go to a woman than would be the case, should she have to face off against a male - either at the party selection

\footnotetext{
12 Ryan, Michelle K., S. Alexander Haslam, and Clara Kulich. 2010. "Politics and the Glass Cliff: Evidence That Women Are Preferentially Selected to Contest Hard-to-Win Seats." Psychology of Women Quarterly 34(1): 5664.

13 Śledzińska-Simon, Anna, and Adam Bodnar. 2013. "Gender Equality from Beneath: Electoral Gender Quotas in Poland." Canadian Journal of Law \& Society / La Revue Canadienne de Droit et Société 28(2): 151-68. Page 165.

${ }^{14}$ Brodolini, Fondazione Giacomo, Lenita Freidenvall, Stahre Hedvig, and Silvia Sansonetti. 2014. Electoral Lists Ahead of the Elections to the European Parliament from a Gender Perspective PE 509.980.

${ }^{15}$ Lühiste, Maarja. 2015. "Party Gatekeepers' Support for Viable Female Candidacy in PR-List Systems." Politics \& Gender 11(1): 89-116.

$16 \mathrm{lbid}$.

17 Schwindt-Bayer, Leslie A. 2005. "The Incumbency Disadvantage and Women's Election to Legislative Office." Electoral Studies 24(2): 227-44.
} 
or at the general election stage. While present in some European executive branches, term limits remain absent - at least in formal, legal terms - from each of the European legislatures.

Finally, electoral engineering might also be used to increase women's descriptive representation via the openness of ballot designs. Whereas most European political systems use some degree of proportional representation (PR) in their national elections and are legally obliged to do so for European elections, a number of more nuanced decisions vary widely. These include aspects such as the district magnitudes (length) of each electoral list and how much choice individual voters are given to indicate preference for specific candidates (e.g., open $\mathrm{v}$ closed lists). In terms of gendered representation, Fortin-Rittberger and Rittberger find that larger district magnitudes (i.e., higher numbers of elected representatives/ candidates per territorial area) naturally promote greater numbers of female legislators within Europe, but also that these lists must be ordered ahead of time by the party and not open to change by voters who might have an incentive to downgrade women from positions that are likely to win. 18

In separate studies, Lühiste 19 and Aldrich20 also find that variation in PR system rules can have positive and negative effects on women. Variation in these electoral rules for the EP elections in 2014 led to a great deal of variance in the number of women nominated, and then subsequently elected, on party lists. Of the 28 member states, only seven used closed PR lists, while 19 used some form of open or voter-preference lists. Two states, Malta and Ireland, used a single transferable voting (STV) system. Across all 28 countries, the average number of women nominated on closed lists was about $38 \%$, open lists about $36 \%$ and STV lists about $32 \%$. In addition, Belgium, France, Greece, Poland, Portugal, Slovenia, and Spain had nationally-mandated quotas in place. Because of the specific quota requirements, France had the most women, both nominated and then elected, at $49.9 \%$ and $42 \%$ respectfully. Belgium nominated about $48 \%$ women but with only about $30 \%$ elected. In non-quota states, the country with the most women in its delegation was Malta at 67\%, followed by Ireland and Sweden at $55 \% .21$

Whereas a number of political parties - and even entire countries - have taken the 'hard' regulatory perspectives that are mentioned above to boost women's descriptive representation, our initial discussion of work by both Dahlerup22 and Tremblay23 reminds us that gendered representation may not only be the purview of institutional mechanisms, but also more holistic choices from within political party organization. Here we begin with a discussion of policies that can boost the recruitment and selection of female candidates at the party level, before discussing additional patterns found among certain party cultures.

\footnotetext{
${ }^{18}$ Fortin-Rittberger, Jessica, and Berthold Rittberger. 2014. “Do Electoral Rules Matter? Explaining National Differences in Women's Representation in the European Parliament." European Union Politics 15(4): 496-520. 19 Lühiste, Maarja. 2015. "Party Gatekeepers' Support for Viable Female Candidacy in PR-List Systems." Politics \& Gender 11(1): 89-116.

20 Aldrich, Andrea S. 2018. "Party Organization and Gender in European Elections." Party Politics: 135406881880663.

${ }^{21}$ Aldrich, Andrea S. 2018. "Party Organization and Gender in European Elections." Party Politics: 135406881880663.

22 Dahlerup, Drude. 2006. Women, Quotas and Politics. Taylor \& Francis.

${ }^{23}$ Tremblay, Manon. 2012. Women and Legislative Representation: Electoral Systems, Political Parties, and Sex Quotas. Palgrave Macmillan.
} 
To recall Matland's previous discussion of a recruitment environment,24 we know that it is essential for parties to combine electoral system choices with a recruitment culture that lends itself to increasing women's representation. Fortin-Rittberger and Rittberger discuss the pros and cons of an inclusive party selectorate for female candidates in Europe, finding a mixed bag of results. 25 When parties select candidates at a very broad level (as in a party primary), women oftentimes face the same hurdles to selection as they would in an open-list race (but see some contrasting evidence from Iceland in Indriðason and Kristinsson).26 However, more highly centralized selectorates leave women at the mercy of a small set of selectors - who may more effectively prioritize or de-prioritize their selection.27 In other words, more party centralization in candidate selection typically, but not always, boosts female descriptive representation.

Fortin-Rittberger and Rittberger further discuss this quandary within the context of territorial centralization, where more federated party organizations could open the door to more heterogenous selections that privilege either pluralism or narrow, local-based interests. 28 This suggests that when parties are more decentralized (as would be more likely in territoriallydecentralized regimes, such as under federalism), their effect on gendered recruitment patterns is more likely to be outweighed by the prevailing political culture dominating the selection process at lower levels.

Another dimensionality relates to party ideology. Whereas Europe's green and centre-left parties have historically been the home of gender parity in recruitment and selection, the most experienced female politicians oftentimes come from the centre-right - suggesting a somewhat counterintuitive finding between inclusive recruitment and individual quality. 29 This finding is similar to the broader findings of Xydias,30 who shows that more gender-equal groups and societies do have a positive effect of women's selection and election, but offices that are perceived as more important are oftentimes still dominated by male candidates. 31

Finally, other authors note differences in the level of office and its location. For the case of the European Parliament, Fortin-Rittberger and Rittberger note the broad, ideological affinity of

\footnotetext{
24 Matland, Richard. 2006. "Electoral Quotas: Frequency and Effectiveness." In Women, Quotas and Politics, ed. Drude Dahlerup. New York: Routledge, 275-92.

${ }^{25}$ Fortin-Rittberger, Jessica, and Berthold Rittberger. 2015. "Nominating Women for Europe: Exploring the Role of Political Parties' Recruitment Procedures for European Parliament Elections." European Journal of Political Research 54(4): 767-83.

${ }^{26}$ Indriðason, Indriði H, and Gunnar Helgi Kristinsson. 2015. "Primary Consequences: The Effects of Candidate Selection through Party Primaries in Iceland." Party Politics 21(4): 565-76.

27 Aldrich, Andrea S. 2018. "Party Organization and Gender in European Elections." Party Politics: 135406881880663; Pruysers, Scott, William P. Cross, Anika Gauja, and Gideon Rahat. 2017. "Candidate Selection Rules and Democratic Outcomes: The Impact of Parties on Women's Representation." In Organizing Political Parties Representation, Participation, and Power, eds. Susan E Scarrow, Paul D. Webb, and Thomas Poguntke. Oxford: Oxford University Press.

${ }^{28}$ Fortin-Rittberger, Jessica, and Berthold Rittberger. 2015. "Nominating Women for Europe: Exploring the Role of Political Parties' Recruitment Procedures for European Parliament Elections." European Journal of Political Research 54(4): 767-83.

${ }^{29}$ Lühiste, Maarja, and Meryl Kenny. 2016. "Pathways to Power: Women's Representation in the 2014 European Parliament Elections." European Journal of Political Research 55(3): 626-41.

${ }^{30}$ Xydias, Christina. 2016. "Discrepancies in Women's Presence between European National Legislatures and the European Parliament: A Contextual Explanation." Political Research Quarterly 69(4): 800-812.

${ }^{31}$ See also: Krook, Mona Lena. 2010. "Why Are Fewer Women than Men Elected? Gender and the Dynamics of Candidate Selection." Political Studies Review 8(2): 155-68.
} 
pro-EU policies as also being seen as 'pro-female'.32 This leads to the EP being seen as particularly woman-friendly - a fact that is further enhanced by its relatively youthful mean age and flexible working environment. Chiva also identifies pro-EU with pro-female in her study of Central and East European political parties, where the pro-EU parties are much more likely to recruit and select female politicians than are the more heavily nationalist and parochial ones.33

Overall, political parties are the main drivers of gender equality (or lack thereof) in the European Parliament. Because many factors contribute both to party culture and electoral strategy, it is hard to determine any hard and fast rules to ensure gender equality in all parties and all countries. What research has shown is that electoral rules and gender quotas interact with party selection rules to determine the number of women nominated to party lists and the list placement of each candidate.

When party memberships have control over selection, the lists, and their subsequent gender equality is decided more by voter preference. When selection is exclusive, and conducted mostly by party elites, then the list reflects the preferences of party leadership. This conditions the effects of quotas, electoral rules, and party culture. In European elections, quotas are more effective at increasing the number of women on party lists in open-list systems where average voters or party members may not see equality as a priority. Conversely, parties in closed-list systems already tend to nominate more women and have been shown to be more reactive to electoral demands when considering the optimum list configuration.34 In sum, the representation of women depends upon a multitude of elements that must be considered by parties and voters.

\subsection{Executive representation within the European Commission and Council of the EU}

Gender balance in the EU's executive leadership is also contingent on both institutional-legal structures and political culture within member states. While there are no legal rules or laws at the EU level that require gender balance in either the Commission or the Council of the EU, several policies are in place that actively promote gender balance in decision-making, both within the EU's executive institutions and within member state national governments. The effectiveness of these policies ultimately rests in the hands of national political elites.

Kantola identifies three major periods in the development of policies to promote equal gender representation in the EU's and member state's decision-making processes. 35 The first period began in the early 1990s when the Commission adopted the Third Action Programme on Equal Opportunities for Women.36 The program stated that the active participation of women in decision-making could be one of the most efficient ways to achieve equal opportunity. It suggested that the Commission would work with the EP, political parties, and member states to raise awareness of the importance of women in decision-making and increase women's

\footnotetext{
32 Fortin-Rittberger, Jessica, and Berthold Rittberger. 2014. “Do Electoral Rules Matter? Explaining National Differences in Women's Representation in the European Parliament." European Union Politics 15(4): 496-520.

${ }^{33}$ Chiva, Cristina. 2012. "Gender, European Integration and Candidate Recruitment: The European Parliament Elections in the New EU Member States." Parliamentary Affairs: 1-37.

34 Aldrich, Andrea S. 2018. "Party Organization and Gender in European Elections." Party Politics: 135406881880663.

35 Kantola, Johanna. 2010. Gender and the European Union. Macmillan International Higher Education.

${ }^{36}$ Commission of the European Communities. 1991. "Equal Opportunities for Women and Men the Third Medium-Term Community Action Programme 1991-1995."
} 
representation at the European and national levels. It also sought to create an expert network, "Women and Decision Making," to research barriers to women's representation and collect data on indicators of gender equality across members states. Thus the Commission committed to funding research and monitoring of women's participation.

Kantola also identifies other pieces of EU policy during this time, including the Athens Declaration of 1991, the Charter of Rome in 1996 and a Council resolution balancing the participation of women and men in decision-making in 1995.37 This resolution38 reaffirmed a commitment to gender balance in decision-making and stated that the balancing of responsibilities between men and women in "every sphere of life" was necessary to achieve to equality between men and women. To this end, the resolution recommended that member states adopt the objectives of the resolution to promote gender balance in their government programs, including balanced participation "in decision making in the political, economic, social and cultural fields". Of course gender balance in government representation at the national level, and subsequently at the European level was difficult to achieve quickly.

A second period of policy making (1996-2000) included even more calls to action by member state governments to both acknowledge the difficulties in achieving gender balance and to establish benchmarks to measure progress. Nine such benchmarks were identified in 1999 by the Council that showed women's representation was abysmally low at both the EU and the national levels.39 The third period identified began in 2000, when the EP asked for a report from the Commission on the status of women's representation and the Commission responded with a report that established a minimum baseline goal of $40 \%$ representation for women in committees and expert groups in the EU. The Commission also launched a database to establish progress, "Women and Men in Decision Making: A database with Facts and Figures," in 2004.40

In more recent time periods, the Commission has continued to issue policy goals related to the equal representation of women and the implementation of the Council resolution. Several action plans and roadmaps for achieving women's equal representation in both the economy and government have been written, but these remain mostly informal, using tools like information campaigns, the collection of data and definition of indicators of equality, and encouraging "examples of good progress" (Kantola 2010, 55-56).41

In 2016, the Commission issued another plan to action for gender equality that reaffirmed its commitment to the previously stated goal of reaching $40 \%$ women in decision-making roles in all aspects of public life within the EU.42 The Strategic Engagement for Gender Equality 20162019 stated the goals of improving gender balance in political decision-making and public life and also of achieving at least $40 \%$ women in senior and middle-management positions within the Commission by 2019. The action proposed included "continuing to encourage Member States and support national authorities' activities promoting gender balance in political and

\footnotetext{
${ }^{37}$ Kantola, Johanna. 2010. Gender and the European Union. Macmillan International Higher Education.

${ }^{38}$ Council of the European Union. 1995. "Council Resolution of 27 March 1995 on the Balanced Participation of Men and Women in Decision Making (95/C 168/02)."

${ }^{39}$ Kantola, Johanna. 2010. Gender and the European Union. Macmillan International Higher Education.

${ }^{40}$ Kantola, Johanna. 2010. Gender and the European Union. Macmillan International Higher Education.

${ }^{41}$ Kantola, Johanna. 2010. Gender and the European Union. Macmillan International Higher Education.

42 European Commission. 2015. "Strategic Engagement for Gender Equality 2016-2019."
} 
public decision making positions" (71). At the time of the plan's writing, the representation of women was about $28 \%$ in senior management and $32 \%$ in middle management.

While each of these steps highlights the EU's view that equal representation of genders across executive political bodies is desirable, this $40 \%$ minimum target has proven difficult to achieved in most member state governments and within the EU institutions themselves. Table 1 displays the percentage of women in senior administrative positions throughout the EU from 1999 through 2018. As the data shows, the number of women as a share of all positions has grown steadily since 1999, but still falls short of the target

On average, the institution with the most balanced gender representation in senior positions is the EP, although the percentage of women in leadership fluctuates quite a bit over the years. This is not surprising, given the concrete, and sometimes legislated, measures that member states implement to encourage women's elected representation at the legislative level.

In addition, an increase in the number of female MEPs also expands the pool of candidates from which to draw leadership positions in the other EU institutions. The Commission has experienced an increase in the representation of women in senior positions in every year since 1999, nearly tripling from $13.5 \%$ in 1999 to $33.9 \%$ in 2018. Many of these women are recruited from previous national or European legislative careers. However, this is still shy of the selfproclaimed $40 \%$ target. Overall, the last column of Table 1 shows the total distribution of women in senior administrative positions is now just above $32 \%$.

Table 1: Percentage of Women in Senior Administrative Positions in EU Institutions

\begin{tabular}{lllll} 
Time & $\begin{array}{c}\text { College of } \\
\text { Commissioners }\end{array}$ & $\begin{array}{c}\text { Council of } \\
\text { the EU }\end{array}$ & $\begin{array}{c}\text { European } \\
\text { Parliament }\end{array}$ & Total \\
\hline 1999 & 13.5 & 12.8 & 16.1 & 13.6 \\
2003 & 13.1 & 14.5 & 19.4 & 13.9 \\
2004 & 14.8 & 18.2 & 23.1 & 16.2 \\
2005 & 16.9 & 17.8 & 22 & 17.6 \\
2006 & 16.3 & 17.3 & 26.5 & 17.2 \\
2007 & 18.2 & 15.7 & 33.3 & 19.5 \\
2008 & 19.9 & 14.8 & 40.7 & 21.8 \\
2009 & 20.8 & 16.1 & 41.1 & 23.4 \\
2010 & 21.5 & 17.5 & 41.3 & 24.1 \\
2011 & 24.1 & 17.4 & 34.5 & 25.4 \\
2012 & 25.7 & 17.8 & 39.2 & 27.7 \\
2013 & 27.5 & 20 & 38.6 & 29.1 \\
2014 & 27.7 & 20 & 32.2 & 27.5 \\
2015 & 29.4 & 22.2 & 32.1 & 29 \\
2016 & 29.1 & 25 & 30.4 & 28.9 \\
2017 & 32 & 31.7 & 29.3 & 31.6 \\
2018 & 33.9 & 29.3 & 25.4 & 32.4 \\
\hline Average All & 22.6 & 19.3 & 30.9 & 23.5 \\
Average $<2010$ & 16.7 & 15.9 & 27.8 & 17.9 \\
Average $\geq 2010$ & 27.9 & 22.3 & 33.7 & 28.4 \\
\hline S2 & 27.9 & &
\end{tabular}

Source: The European Database: Women in Decision-making 
The Council of the European Union remains the institution with the lowest gender equality. Because ministers are drawn from member state governments, the EU has the least amount of control over who is selected into government ministries. Much like parliamentary selection, the responsibility to promote women to these types of leadership posts rests with political parties and is influenced by the political, structural, and cultural aspects within each member state. Thus there is a large amount of variance across the member states.

Table 2 presents the percentage of women holding cabinet-level positions in each member state from 2004 to 2019. Unlike the Commission, the percentage of women in senior ministerial positions has not grown steadily over time. Instead, it appears to fluctuate year-on-year, likely as governments change within member states. The state with the lowest average number of women in this table is Hungary, where there is a sharp decline in the percentage of women in the cabinet after FiDeSz came to power in 2008. Other counties with a low average percentage of women also come from the 2004 expansion states of Slovakia, Estonia, Lithuania, and the Czech Republic. While these state have average percentages lower than 16, a handful of states do come close to, or surpass the $40 \%$ target. These include France, Germany, Spain, Finland, and Sweden. Sweden has the highest average, with about $50 \%$, and very low variance throughout the years reported in the table. This may indicate the success of early gender quotas, finally taking hold within the Swedish system, while also recalling the length of time needed to effect real change in descriptive representation.

Table 2: Percentage of Women in Senior Ministerial Positions in National Governments

\begin{tabular}{llllllll}
\hline Country & $\mathbf{2 0 0 4}$ & $\mathbf{2 0 0 8}$ & $\mathbf{2 0 1 2}$ & $\mathbf{2 0 1 6}$ & $\mathbf{2 0 1 9}$ & Average & Std. Dev \\
\hline Austria & 36.4 & 35.7 & 42.9 & 21.4 & 38.5 & 35.0 & 8.1 \\
Belgium & 21.4 & 40.0 & 38.5 & 21.4 & 23.1 & 28.9 & 9.5 \\
Bulgaria & 27.3 & 26.3 & 23.5 & 47.4 & 30.0 & 30.9 & 9.5 \\
Croatia & -- & 22.2 & 13.6 & 19.0 & 23.8 & 19.7 & 4.5 \\
Cyprus & 0.0 & 8.3 & 33.3 & 8.3 & 16.7 & 13.3 & 12.6 \\
Czech Republic & 11.8 & 11.1 & 12.5 & 17.6 & 26.7 & 15.9 & 6.5 \\
Denmark & 29.4 & 36.8 & 43.5 & 29.4 & 40.9 & 36.0 & 6.5 \\
Estonia & 8.3 & 21.4 & 7.7 & 13.3 & 20.0 & 14.1 & 6.4 \\
Finland & 47.1 & 60.0 & 47.4 & 35.7 & 35.3 & 45.1 & 10.2 \\
France & 17.6 & 34.2 & 48.7 & 47.4 & 50.0 & 39.6 & 13.8 \\
Germany & 46.2 & 37.5 & 37.5 & 37.5 & 43.8 & 40.5 & 4.2 \\
Greece & 6.3 & 11.1 & 5.6 & 0.0 & 21.7 & 8.9 & 8.1 \\
Hungary & 11.8 & 12.5 & 9.1 & 0.0 & 7.1 & 8.1 & 5.0 \\
Ireland & 21.4 & 20.0 & 13.3 & 26.7 & 26.7 & 21.6 & 5.6 \\
Italy & 8.7 & 18.2 & 15.8 & 29.4 & 27.8 & 20.0 & 8.6 \\
Latvia & 25.0 & 21.1 & 28.6 & 21.4 & 28.6 & 24.9 & 3.7 \\
Lithuania & 15.4 & 14.3 & 13.3 & 28.6 & 0.0 & 14.3 & 10.1 \\
Luxembourg & 16.7 & 20.0 & 26.7 & 20.0 & 29.4 & 22.6 & 5.3 \\
Malta & 15.4 & 22.2 & 18.2 & 5.9 & 13.3 & 15.0 & 6.1 \\
Netherlands & 31.3 & 27.8 & 38.5 & 38.5 & 37.5 & 34.7 & 4.9 \\
Poland & 6.3 & 25.0 & 20.0 & 27.3 & 26.1 & 20.9 & 8.6
\end{tabular}




\begin{tabular}{llllllll} 
Portugal & 16.7 & 11.8 & 16.7 & 22.2 & 27.8 & 19.0 & 6.1 \\
Romania & 11.8 & 0.0 & 19.0 & 36.4 & 24.0 & 18.2 & 13.6 \\
Slovakia & 0.0 & 6.3 & 7.1 & 13.3 & 33.3 & 12.0 & 12.8 \\
Slovenia & 7.1 & 16.7 & 7.7 & 47.1 & 23.5 & 20.4 & 16.4 \\
Spain & 43.8 & 50.0 & 28.6 & 27.3 & 58.8 & 41.7 & 13.6 \\
Sweden & 50.0 & 45.5 & 54.2 & 50.0 & 52.2 & 50.4 & 3.2 \\
United Kingdom & 26.1 & 32.0 & 16.7 & 34.8 & 21.7 & 26.3 & 7.4 \\
\hline
\end{tabular}

Source: the European Database: Women in Decision-making (please note each figures is for the 4th quarter of the given year with the exception of 2019 which is the 2 nd quarter.

The total representation of women within member state cabinets is one way to measure the representation of women in the Council, but it is also important to examine gendered patterns or representation across policy areas. When women began to enter the political space and gain positions of executive power, they typically appeared first in areas related to private life. These policy areas, like social welfare, families and children, and culture were typically considered to be 'soft' policy areas.43 These policy areas are often juxtaposed with 'hard' policy areas like defense, foreign policy, and finance that are typically associated with men in the public sphere. Women in these positions is a relatively new phenomenon. 44

As expected, women's ministerial representation across EU member states largely resemble this pattern. For example, men outnumbered women at a rate of 3.5-to-1 as foreign ministers in 2009. By 2013, this ratio had grown to 5 to 1 . The only policy area where women outnumber men in the Council is the configuration for Education, Youth Culture and Sport, but even this did not occur until 2017.45 In addition to ministerial positions within the Council, the Permanent Representatives Committee (Coreper) is also largely male dominated. In 2007, there was only one female permanent ambassador to Coreper II and only 6 women serving on Coreper I.46 As with all other patterns of executive life in the EU, descriptive representation remains the product of national decision-making and norms, where they do exist, are both slow to change and relatively lacking in enforceable institutional teeth.

\subsection{Judicial representation within the Court of Justice of the EU}

The Court of Justice for the European Union is another institution that can both descriptively and substantively represent women in the EU. Unlike the other institutions that we have

\footnotetext{
43 See, for example: Davis, Rebecca Howard. 1997. Women and Power in Parliamentary Democracies: Cabinet Appointments in Western Europe, 1968-1992. University of Nebraska Press; Escobar-Lemmon, Maria, and Michelle M. Taylor-Robinson. 2009. "Getting to the Top: Career Paths of Women in Latin American Cabinets." Political Research Quarterly 62(4): 685-99 and

Krook, Mona Lena, and Diana Z O'Brien. 2012. "All the President's Men? The Appointment of Female Cabinet Ministers Worldwide." The Journal of Politics 74(03): 840-855.

44 See Barnes, Tiffany D., and Diana Z. O'Brien. 2018. "Defending the Realm: The Appointment of Female Defense Ministers Worldwide." American Journal of Political Science 62(2): 355-68; Escobar-Lemmon, Maria, and Michelle M. Taylor-Robinson. 2009. "Getting to the Top: Career Paths of Women in Latin American Cabinets." Political Research Quarterly 62(4): 685-99 and Escobar-Lemmon, Maria C., and Michelle M. TaylorRobinson. 2016. Women in Presidential Cabinets: Power Players or Abundant Tokens? Oxford University Press. https://www.oxfordscholarship.com/view/10.1093/acprof:oso/9780190491420.001.0001/acprof9780190491420 (July 12, 2019).

45 Aldrich, Andrea S, and Lauren K. Perez. 2019. "Losing Women \& Losing Power? Gender, Turnover, and EU Legislation." Presented at the 2019 European Union Studies Association Conference, Denver.

${ }^{46}$ Kantola, Johanna. 2010. Gender and the European Union. Macmillan International Higher Education.
} 
previously discussed, however, the goal of gender equality in the court has been less pronounced and the presence of women on the court has been lower. The "Women and men in decision making database" created by the Commission also tracks the gender representation of the ECJ/CJEU. ${ }^{47}$ In 1999, only $7.7 \%$ of judges were female, with only three serving on the court. 10 years later, this percentage increased to $19.7 \%$, with 12 female members on the court. In 2018, there were 15 women (20.3\%). Obviously this is significantly lower than the number of women in higher level positions of the other EU institutions. In addition, there has yet to be a female president of the court.

However, like member state governments, recruitment for the court takes place within the realm of national politics. Each member state determines their own process for the appointment of judges. These process within member states are often described as secretive and political, managed by elites where access to networks, high-level political actors, and political parties is necessary.48 These networks are typically harder for women to access and make it more difficult for them to reach top political positions, 49 which can include positions on the Court. Women are similarly underrepresented as Advocates General. As of Kantola's (2010) writing, only five women had ever served in the important role.50

While women have been underrepresented on the CJEU, the court has, at times, been an important source of the substantive representation for women and a guarantor of gender equality across the EU, making several important decisions to help and ensure equality across the sexes and across the Member States. While legal rules ensuring equal access to political office remain in the purview of national governments (e.g., quotas), gender equality first entered the treaties of the European Community with the Treaty of Rome in 1957, which featured a provision of equal pay for equal work (Article 119). The Treaty of Amsterdam then established gender equality as a fundamental task of the EU (Article 2) in 1999 and the Treaty of Lisbon again enshrined the equal treatment of men and women into community law.51 Article 2 of the Treaty of the European Union (TEU) specifically guarantees equality between men and women stating,

"The Union is founded on the values of respect for human dignity, freedom, democracy, equality, the rule of law and respect for human rights, including the rights of persons belonging to minorities. These values are common to the Member States in a society in which pluralism, non-discrimination, tolerance, justice, solidarity, and equality between men and women prevail."

To this effect, the Treaty of the Functioning of the European Union (TFEU) also states in Article 8, "In all its activities, the Union shall aim to eliminate inequalities, and to promote equality between men and women" and requires the Union to "... aim to combat discrimination based on sex..." (Article 10 TFEU). Article 157 TFEU ensures equal pay for equal work

\footnotetext{
47 These data can be found here: https://eige.europa.eu/genderstatistics/dgs/indicator/wmidm jud eucrt wmid eucrt/hbar/chart/year:2018/geo:EU/EGROUP:CRTS EUR/s ex:M,W/UNIT:PC/POSITION:MEMB CRT/ENTITY:CST,ECHR,GC,CJEU,ECJ accessed July 12, 2019.

48 Kenney, Sally J. 2002. "Breaking the Silence: Gender Mainstreaming and the Composition of the European Court of Justice." Feminist Legal Studies 10(3): 257-70.

49 Verge, Tània, and Javier Astudillo. 2018. "The Gender Politics of Executive Candidate Selection and Reselection." European Journal of Political Research.

50 Kantola, Johanna. 2010. Gender and the European Union. Macmillan International Higher Education.

${ }^{51}$ For a discussion of gender equality in all EU and EC treaties see http://www.genderequality.ie/en/GE/Pages/WP13000032 accessed October 16, 2019.
} 
between men and women and "guarantees that the principle of equal treatment shall not prevent any Member State from maintaining or adopting measure providing for specific advantages in order to make it easier to...compensate for disadvantages in professional careers."

These provisions are what Holzleithner (2018) calls "transformative" and have opened up the path for several legislative directives from the EP that have pushed for gender equality.52 However, as Holzleithner points out, directives must be implemented by member states and she identifies a few key cases heard by the ECJ/CJEU that helped increase gender equality by ensuring that these directives were interpreted correctly.53

The case of Defrenne $v$ Sabenas4 ruled on the equal pay between men and women with reference to (the then) Article 119 of the Treaty of the European Communities and Article 157 of TFEU. Its ruling established that the equal pay provision applied not only to relationships between individuals and the government but also between private parties. The ruling also established that gender equality was not just an economic objective, but a social one as well.55 Another important decision of the Court came in Marshall vs. Land Nordrhein-Westfalen, 56 where the Court ruled in favor of affirmative action measures meant to facilitate the employment of women. In this case, the Court ruled on a national law where, if men and women were equally qualified, priority could be given to a female candidate unless there was some reason specific to an individual male that would preference him. The Court determined that this type of priority for female candidates would not violate the principal of equal treatment of men and women. ${ }^{57}$

Thus, at times, the Court has provided an important check on the implementation of gender equality and women's representation in the EU. As these cases highlight, there are times when it is the responsibility, and right, of the Court to provide guidance on the application gender equality law. National courts are required to consult the CJEU when it is unclear whether gender equality in national laws meet the obligations set forth by EU law. The CJEU issues a ruling that is then binding in all Member states and sets the legal standards to which gender equality must adhere. 58

However, there are also instances where the courts have upheld practices of discrimination, citing gender equality as the legitimizing principle. Holzleithner (2018) highlights Lisa Grant $v$ South West Trains Ltd as one such example. In this case, a female employee was denied a benefit for her same-sex co-habitant that would not have been denied to a co-habitant of the opposite sex. Thus, it was argued that this benefit was denied on the basis of gender discrimination and would not have been denied to colleagues with co-habitants of the opposite

\footnotetext{
52 Holzleithner, Elizabeth. 2018. "Subversion from Within Opposition to Gender Equality in the Court of Justice of the European Union." In Varieties of Opposition to Gender Equality in Europe, ed. Mike Verloo. London: Routledge.

53 Ibid.

54 Case C-149/77

55 Holzleithner, Elizabeth. 2018. "Subversion from Within Opposition to Gender Equality in the Court of Justice of the European Union." In Varieties of Opposition to Gender Equality in Europe, ed. Mike Verloo. London: Routledge.

${ }^{56}$ Case C-409/95

57 https://eur-lex.europa.eu/legal-content/EN/TXT/?uri=CELEX:61995CJ0409\#SM

58 Holzleithner, Elizabeth. 2018. "Subversion from Within Opposition to Gender Equality in the Court of Justice of the European Union." In Varieties of Opposition to Gender Equality in Europe, ed. Mike Verloo. London: Routledge.
} 
sex. The CJEU upheld the refusal of the benefit, given the employer would also have denied the benefit to male co-habitants of the same sex. In so doing, it essentially ruled that this type of discrimination adhered to a principle of gender equally, because it would affect same-sex couples of any gender equally.

In addition, the continued dominance of men in the institution can affect its legitimacy, in terms of representation.59 The absence of women in the judiciary can lead to the absence of important perspectives. Similar to arguments made about the effect of descriptive representation in legislative and executive institutions, diverse representation in judicial institutions can increase the quality of deliberation and the range of perspective considered in the application of the law. Women's shared experiences in both the private and public sectors of society can contribute to decision-making in ways that men's experience cannot. As issues related to gender equality bring questions before courts that deal with all aspects of life, the presence of women and their unique perspective may help to promote gender equality. 60

In addition, the ability of all political institutions to deliberate and deliver resolutions is generally improved when diverse perspectives are allowed to participate. Diversity in representation allows for the consideration of heterogeneous perspectives, which in turn strengthens ties between citizens and their representative institutions.61 If the EU is dedicated to gender equality, it must practice this both with its law-making, but also within its own institutions.

\section{Conclusion}

While the European Union has made significant progress toward gender equality within its institutions, there is still room for growth in women's representation among the most powerful decision-making bodies. The EP elections in 2019 showed many of the same patterns as previous elections, but the percentage of women increased overall to $41 \%$ of new MEPs. This is a 4\% increase compared to $37 \%$ in the 2014-2019 session.62 Seven countries surpassed the $40 \%$ benchmarks, with Sweden and Finland electing the greatest number of female MEPs (55\% and 54\% of their delegations respectively). Central and Eastern European countries still came up short, with Slovakia, Romania, Bulgaria, and Greece electing the lowest percentage of women in their delegations. Cyprus elected no women to its six-person delegation. 63

Additional gains for women's representation among the EU executive institutions could come from the 2019 process to select a new Commission president. After the failure or the Spitzenkandidaten process to produce an acceptable candidate to the member states, the European Council nominated Ursula von der Leyen, the German defense minister from the

\footnotetext{
${ }^{59}$ van der Vleuten, Anna. 2007. The Price of Gender Equality: Member States and Governance in the European Union. London: Routledge.

${ }^{60}$ Hoekstra, Valeria, Miki Caul Kittilson, and Elizabeth Andrews Bond. 2014. "Gender, High Courts, and Ideas about Representation in Western Europe" in Representation The Case of Women, eds. Maria C. EscobarLemmon and Michelle M. Taylor-Robison. New York: Oxford University Press.

61 Mansbridge, Jane. 1999. "Should Blacks Represent Blacks and Women Represent Women? A Contingent "Yes"." The Journal of Politics. 61(3): 628-57.

62 Raibagi, Kashyap. 2019. "European Elections: Closing in on Target for Gender Parity in the European Parliament." VoxEurop.eu. https://voxeurop.eu/en/2019/european-parliament-5123486 (July 16, 2019). 63 European Parliament. 2019. "MEPs Gender Balance | 2019 Election Results | 2019 European Election Results | European Parliament." https://election-results.eu/. https://election-results.eu/mep-gender-balance/20192024/ (July 16, 2019).
} 
centre-right, as its preferred candidate.64 She has pledged to work for increased gender equality within the EU. In a speech in support of her candidacy, she called on member state governments to increase gender equality in choosing commissioners and to make sure they are doing their part to achieve parity and stated that she would have a gender equal Commission.65 She also stated that if member states didn't nominate enough women, she would ask for new proposals, calling out their failure to do so in the past and mentioning that only $20 \%$ of commissioners have ever been women (Boffey 2019).66

While the literature is quite clear on the institutional and legal innovations - such as quotas, placement mandates on electoral lists, and nomination benchmarks - that can enhance women's descriptive representation, it is also clear that these processes take time and frequently commingle with the more overtly political process of European integration. Just as we have highlighted the paucity of female MEPs from Cyprus and the surprise nomination of Ursula von der Leyen to the head of the Commission, so too are these choices the product of other political dynamics that are not overtly gendered: the small state of Cyprus' six MEPs hail from nearly as many different parties and the choice of a German defense minister to lead the EU executive is remarkable in and of itself, given the Union's history.

Our work in this chapter has shown that the future of gender equality among the EU institutions depends primarily upon Member State commitments. While treaty and other EU-level benchmarks have led to important increases for women's representation among the European Parliament, Court of Justice, Council, and Commission, the most effective drivers of gender equality remain at the national and sub-national (viz. political party) levels. This supports our opening perspective that 'hard' legal requirements - either by the EU or member state governments' themselves - must also be supplemented and supported by 'softer' social expectations from the European populations themselves.

Much of the existing research that we have presented in this chapter has focused on features of the legal and institutional settings that can encourage or discourage gender equality in the EU's political institutions. However, future research can and should continue to focus on the broader causes and consequences of women's representation. As we have highlighted here, many determinants of equality within the EU's institutions stem from practices within the Member States themselves. Focusing future research on barriers to entry and pathways to power, both within national institutions and among important elite networks, can yield new insights into the career trajectories that women take, or do not take, to reach political office. While we have not touched on this literature here, an important component to the success of gender equality policies and institutional provisions such as quotas is the existence of a pool of women willing to serve in political roles. One avenue for future research could examine the social and economic opportunity costs faced by women that hinders their ability to seek out public office. Bringing in research from both a European and a comparative context can provide fruitful insights into the extra-institutional factors that continue to contribute to both gender equality and inequality.

\footnotetext{
64 Gostynska-Jakubowska, Agata. 2019. “Ursula von Der Leyen Isn't Perfect, but She's Better Than the Alternative." Foreign Policy. https://foreignpolicy.com/2019/07/15/ursula-von-der-leyen-isnt-perfect-butshes-better-than-the-alternative-european-commission-eu-epp-spd-sd/ (July 16, 2019).

65 https://ec.europa.eu/commission/sites/beta-political/files/opening-statement-plenary-session en 2.pdf

66 Boffey, Daniel. 2019. "Half of Commissioners Should Be Women, Says Ursula von Der Leyen." The Guardian. https://www.theguardian.com/world/2019/jul/16/half-of-eu-commissioners-should-be-women-says-ursulavon-der-leyen (July 16, 2019).
} 
In addition to understanding the micro-level processes that affect women's careers, it is also essential to encourage scholars to take an intersectional approach to the study of women, gender, and politics. The inaugural issue of the European Journal of Politics and Gender offers an editorial that highlights pathways for new research, existing literature, and important scholars with the potential to reshape the approach we take in intersectional studies. In this piece, the editors of the journal emphasize the need to look beyond traditional conceptions of gender and to work through certain limitations and exclusions that are inherent in a binary approach to gender and hetero-centric biases. 67

Finally, another growing area of research examines the substantive impact of women's representation in political institutions and the broader impact of increased gender diversity within legislatures, executives, political parties, and judicial institutions. As more women enter into politics and gain important leadership roles, we should be able to determine the effects of their presence on a broader range of subjects. For the time being, we hope that the present contributions has served to connect the topic of women's representation to the volume's focus on politics and the law.

${ }^{67}$ Ahrens, Petra, Karen Celis, Sarah Childs, Isabelle Engeli, Elizabethe Evans, and Liza Mügge. 2019. “Politics and gender: rocking political science and creating new horizons. The European Journal of Gender and Politics. 1(1): 3-25. 
